\title{
6360 Sayılı Yasanın Uygulanmasına Yönelik Halkın Algısı: Hatay Büyükş̧ehir Belediyesi Örneği
}

\author{
DOI: $10.26466 /$ opus. 891398
}

*

\author{
Mehmet Tamer * - Demet Dönmez ** \\ * Dr. Öğr. Üyesi, Hatay Mustafa Kemal Üniveristesi, Antakya MYO, Hatay/Türkiye \\ E-Posta: drmehmettamer1984@gmail.com ORCID: 0000-0001-9806-9548 \\ ** Dr. Öğr. Üyesi, Hatay Mustafa Kemal Üniveristesi, Antakya MYO, Hatay/Türkiye \\ E-Posta: donmezdemet@gmail.com \\ ORCID: $\quad$ 0000-0002-5833-9088
}

\section{Öz}

Ülkemizde büyükşehir uygulaması ilk defa 1984 yılının Mart ayında başlamıştır. Anayasada yer alan büyük yerleşim yerleri için özel yönetimler oluşturulabilir ifadesi, büyükşehirlerin kurulmasının yasal dayanağıdır. Illk büyükşehir olan vilayetler ise İstanbul, Ankara ve İzmir olmuştur. Zaman içerisinde büyükşehir yönetimleriyle ilgili değiş̧iklikler yaşanmıştır. Yeni oluşturulan yasal düzenlemeler ile beraber birçok konuda dönemin şartlarına bağlı olarak gelişmeler kendisini göstermiştir. 1984 yılında başlayan bu değişiklikler en son 2012 yılında gerçekleşmiştir. Bu çerçevede 2012 yıllında çıkarılan 6360 Sayılı Yasa'da yine büyükşehir yönetimlerinde değişikliklere yer veren bir düzenleme olmuştur. Bu yasa ile beraber ülkemizdeki büyükşehir belediyelerinin sayısı artmış ve büyükşehir olmadaki kriter sadece nüfus olarak değiştirilmiştir. Ayruca yeni büyükşehir olan yerlerdeki köy ve belde belediyelerinin tüzel kişilikleri kaldırılarak mahalleye dönüştürülmüştür. Yine büyükşehir statüsüne geçen bu vilayetlerde yeni ilçeler kurulmuştur. Işste bu çalışmada 6360 Sayılı Yasa ile büyükşehir statüsüne geçen Hatay ilinde yapılan hizmetlerin ve ilin büyükşehir olmasıla meydana gelen değişimlerin il halkı nezdinde değerlendirilmesi yapılmış ve yerel halkın Hatay Büyükşehir Belediyesi ve çalışmalarına yönelik algısı ortaya konulmuştur.

Anahtar Kelimeler: Hatay Büyükşehir Belediyesi, 6360 Sayılı Yasa, Büyükşehir Yönetimi, Yerel Halk. 
ISSN:2528-9527

E-ISSN: 2528-9535

Yıl Year: 11

Cilt Volume: 18

Sayı Issue: Yönetim ve Organizasyon Özel Sayısı

Temmuz July 2021

Uluslararası Toplum Araştırmaları Dergisi International Journal of Society Researches

Makalenin Geliş Tarihi Received Date: 04/03/2021

Makalenin Kabul Tarihi Accepted Date: 23/04/2021

\title{
Public Perception about the Implementation of the Law No.6360: The Case of Hatay Metropolitan Municipality
}

*

\begin{abstract}
Metropolitan application in our country started for the first time in March 1984. The statement in the Constitution that special administrations can be established for large settlements is the legal basis for the establishment of metropolitan cities. The provinces, which were the first metropolitan cities, were Istanbul, Ankara and Izmir. Over time, there have been changes regarding metropolitan administrations. Along with the newly created legal regulations, developments have shown themselves in many subjects depending on the conditions of the period. These changes, which started in 1984, were last realized in 2012. In this framework, in the Law No. 6360 enacted in 2012, there was a regulation that included changes in metropolitan administrations. With this law, the number of metropolitan municipalities in our country has increased and the criterion for becoming a metropolitan city has been changed to population only. In addition, the legal entities of the village and town municipalities in the new metropolitan areas were abolished and turned into neighborhoods. New districts have been established in these provinces, which also have metropolitan status. In this study, the services provided in the province of Hatay, which became a metropolitan city with the Law No. 6360, and the changes that occurred with the city being a metropolitan were evaluated by the people of the province and the perception of the local people towards the Hatay Metropolitan Municipality and its work was revealed.
\end{abstract}

Keywords: Hatay Metropolitan Municipality, Law No. 6360, Metropolitan Administration, Local People. 


\section{Giriş}

Yerel halkın ortak olan yerel ihtiyaçlarını temin etmek, idari ve mali özerkliğe haiz kamu tüzel kişiliklerine yerel yönetim denilmektedir. Ülkemizde Anayasamızın 127.maddesinde yerel yönetimler konusunda ayrıntılı bir düzenleme yapılmıştır. İlgili maddeye göre büyük yerleşimler için "özel yönetim" çeşitleri oluşturulabilir ifadesi mevcuttur. Bu ifadeye göre büyük şehirlerdeki belediye yönetimlerini yeniden düzenlemek amacıyla 1984 yılının Mart ayında Bakanlar Kurulu kararıyla çıkarılan "Büyükşehir Belediyelerinin Yönetimi Hakkında Kanun Hükmünde Kararname" kabul edilmiştir. Buna bağlı olarak İstanbul, Ankara, İzmir vilayetlerinde "Büyükşehir Belediyesi" adıyla anakent belediyesi kurulmuştur. Sonraki yıllarda ise bu birimlerin sayısı giderek artmıştır.

Ülkemizde büyükşehir yönetimleri zamanla dönemin farklı şartlarına bağlı olarak gelişmeye başlamışlardır. Büyükşehir olarak adlandırılan yerler ekonominin, iş bölümünün, sanayileşmenin yoğun olduğu yerler olarak ifade edilmeye başlanmış ve buralara yoğun bir göç süreci başlamıştır. Özellikle 1950 yılı sonrası tarımda makineleşmeye bağlı olarak kırdan kente göç süreci büyükşehirlerin sayısını ve bu birimlerin yapılarını etkilemiştir. Büyükşehir belediyesindeki temel nokta merkezde bir anakent belediyesi ve buna bağlı olarak ilçe belediyeleri bulunmaktadır. Büyükşehirler özellikle nüfus açısından diğer belediyelere göre daha yüksek nüfuslu yerleşim yerleridir. Dünya'daki örneklerine bakıldığında Paris, Londra ve Tokyo gibi şehirler karşımıza çıkmaktadır.

Büyükşehirler ile ilgili olarak yasal anlamda tarihsel süreçte önemli düzenlemeler yapılmıştır. Bu anlamda ilk olarak 1984 tarihindeki 3030 Sayılı Kanun çıkarılmıştır. Daha sonra 5216 Sayılı Büyükşehir Belediye Kanunu 2004 yılında çıkarılmıştır. Bu kanun günümüzde halen kullanılmaktadır. En son ise 2012 yılında çıkarılan 6360 Sayılı Kanun olmuştur. Ülkemizde büyükşehir yönetimleri ile ilgili önemli değişikler içeren bir yasal düzenlemedir.

2012 yılında çıkarılan 6360 Sayılı Yasa ile beraber büyükşehirler ile ilgili önemli değişiklikler yaşanmıştır. Bu yasa ile ülkemizde büyükşehir sayısı 30 olmuştur. Hatay, Trabzon, Manisa ve Kahramanmaraş gibi 
vilayetlerin de içinde yer aldığı 14 vilayet büyükşehir statüsüne geçmiştir. Yeni büyükşehir olan vilayetlerde belde belediyeleri ve köyler kapatılmış, bulundukları ilçenin mahallesi olmuşlardır. Yeni büyükşehir olan bu vilayetlerde ayrıca yeni ilçeler kurulmuştur. İl Özel idareleri kapatılmış olup, yerine İl Özel İdaresi ile benzer nitelikteki görevleri icra etmek amacıyla Yatırım İzleme ve Koordinasyon Merkezleri kurulmuştur. Büyükşehir olmadaki kriter nüfus olmuş ve bu sayı da 750 bin olarak belirlenmiştir. Büyükşehirlerin sınırları il mülki sınır olarak değiştirilmiştir. Büyükşehirlerde kadın ve çocuk sığınma evlerinin açılması gibi birtakım düzenlemeler yer almıştır. Bu çalışmamızda 6360 Sayılı Yasa ile büyükşehir statüsüne geçen Hatay vilayetinde büyükşehir yönetiminin çalışmaları ile beraber ilin büyükşehir olmasının yerel halk tarafından algısı ölçülmeye çalışılmıştır. Belirlenen sorular 5'li likert anket yöntemiyle Hatay halkına yönetilmiş ve halkın bakış açısı, algısı değerlendirilmiştir.

\section{Büyükşehir Belediyesi}

Büyükşehrin anakent, bütünşehir, metropol(metropolis), metropoliten alan gibi anlamları mevcuttur (Tekin, 2018, s.85). Türkiye'de büyükşehir belediyeleri 1982 Anayasası'nın 127/3. Maddesinde de belirtildiği üzere "özel yönetim biçimindeki" bir mahalli idare çeşididir (Derdiman, 2012, s.53). 1982 Anayasası'nda yerel yönetimlere bakıldığında esasen üç birimden söz edilmektedir. Bunlar; Köy, Belediye ve İl Özel İdaresidir. Yani anayasada büyükşehirlerin mahalli idare olduğu açıkça yazılı değildir. Ancak "özel yönetim biçimi" ve "kanunla" kurulur ifadeleri büyükşehirleri yasal hale getirmiştir. Ayrıca Anayasa Mahkemesi 2007/35 sayılı kararında büyükş̧ehirleri bir mahalli idare olarak saymıştır (Günday, 2011, s.471). Türkiye'de hem yönetsel hem de nüfus kriterleri açısından belediyeler değerli bir yerel yönetim birimidir ve burada da büyükşehirler kentsel sorumluluk alanları münasebetiyle ön plana çıkmaktadır. Bu yerel idareler tarihsel süreçte önemli değişikliklerden geçmiştir (Zengin, 2014, s.95). Büyükşehir yönetimleri Türkiye'de 1950 sonrası tarımda makineleşmeye bağlı olarak gerçekleşen kentleşmeyle 1960 yılı itibariyle konuşulmaya başlanmıştır (Tekin, 2018, s.85). Ülkemizde büyükşehir modelinin hayata geçirildiği tarih 1984'tür. 
Ancak bu tarihten önce de büyükşehir yönetimi konusunda arayışlar mevcuttur. 1960 yılından sonra arayışlar başlamış, 1984 yılında uygulamaya konulmuş ve 2012 yılında köklü değişiklikler yaşanmıştır (Arıkboğa, 2013, s.50-51). Türkiye'de büyükşehir yönetimleri, kuruldukları günden bu yana gelişim seyri en hızlı olan, en dinamik yerel yönetim birimi olmuştur (Özçelik, 2014, s.1117).

İkinci Dünya Savaşı sonrası dünyada büyük kentlere doğru göç başlamış ve kentleşme süreci hızlanmıştır (Özdemir ve Meşhur, 2011, s.172). Temel olarak bakıldığında İkinci Dünya Savaşı sonrası kentleşme hızının artmasında ve büyükşehirlerin oluşmasında ekonomik, teknolojik ve sosyal değişikliklerin etkili olduğu görülmektedir (Oktay, 1998, s.63-64). Şehirlerin giderek büyümesi, ilçe belediyelerinin birbirlerine oldukça yaklaşması bu sorunların birlikte ele alınmasını zorunlu hale getirmiş ve büyükşehirlerin gerekliliğini ortaya koymuştur (Tortop ve diğerleri, 2006, s.201). Bu bağlamda, büyükşehirlerin yönetimlerine ilişkin başlayan tartışmalar, kentsel alanlarla yönetsel sorumluluk alanlarının birlikte değerlendirilmesi gereğinden hareketle devam etmiştir (Çelikyay, 2014, s.11). Türkiye özelinde büyükşehir belediyesi denildiğinde tüm ilçe belediyeleri, merkezi idareyle ilişkileri, kuruluşu, sınırları, görev ve sorumlulukları, gelir ve giderlerini içeren çok kapsamlı bir olguyu ele almak gerekmektedir (Özgür ve Yavuzçehre, 2016, s.905). Bununla beraber 2012 yılındaki 6360 Sayılı Yasa ile beraber büyükşehir olan yerlerde İl Özel İdarelerinin kapatılması ve il mülki sınır uygulaması büyükşehirlerin hizmet sunma alanını ve yükünü artırdığı söylenebilir (Kızılboğa ve Alıcı, 2013, s.355). Genel olarak 5216 Sayılı Büyükşehir Belediye Kanuna göre büyükşehir denildiğinde; "sınırlar il mülki sınırı olan ve sinırlarn içerisindeki ilçe belediyeleri arasında koordinasyonu sağlayan; idarî ve malî özerkliğe sahip olarak kanunlarla verilen görev ve sorumluluklar yerine getiren, yetkileri kullanan; karar organı seçmenler tarafindan seçilerek oluşturulan kamu tüzel kişisini ifade etmektedir" $(\mathrm{md} / 3)$. 
Tablo.1. Yıllara ve Yasalara Göre Büyükşehir Olan Vilayetler

\begin{tabular}{lll}
\hline YIL & YASAL DÜZENLEME & ŞEHIR \\
\hline 1984 & "3030 Sayılı Kanun" & "İstanbul, Ankara, İzmir" \\
1986 & "3306 Sayılı Kanun" & "Adana" \\
1987 & "3391,3398 ve 3399 Sayılı & "Bursa, Gaziantep, Konya" \\
& Kanunlar" & "Kayseri" \\
1988 & "3508 Sayılı Kanun" & "Antalya, Diyarbakır, Erzurum, Eskişehir, \\
1993 & "504 Sayıll KHK" & İzit(Kocaeli), Mersin, Samsun" \\
& & "Adapazarı (Sakarya)" \\
2000 & "593 Sayıll KHK" & "Aydın, Ballkesir, Denizli, Hatay, Malatya, \\
2012 & "6360 ve 6447(1) Sayılı & Manisa, Kahramanmaraş, Mardin, Muğla, \\
Yürürlük & Kanun" & Tekirdağ, Trabzon, Şanliurfa, Van, Ordu(1)" \\
(2014) & &
\end{tabular}

Kaynak: Yazarlar tarafindan oluşturulmuştur.

\section{Sayılı Yasa ve Getirdikleri}

6360 Sayılı Yasa, mevut 5216 Sayılı Büyükşehir Belediye Yasasında yapılan düzenlemeye bağlı olarak gerçekleşen ve yerel yönetimler alanında genel olarak düzenlemeler ön gören bir çalışmadır (Yılmaz ve Kaypak, 2019, s.4). 6360 Sayılı Yasa 2012 yılında çıkarılan ve 2014 yılında yürürlüğe giren bir hukuki düzenlemedir (Tekin, 2018, s.85). 6360 Sayılı Yasanın bir diğer özelliği ise büyükşehir yönetimlerinde yetki ve sorumluluk noktasında önemli değişiklikleri içermesidir (Yılmaz ve Kaypak, 2017, s.408). Bu değişiklikler beraberinde kamu hizmeti sunma noktasında büyükşehir belediyelerini başat konuma taşımıştır (Günal vd., 2014, s.67). Çünkü büyükşehir belediyeleri yerel hizmet üretmenin yanı sıra gündelik yaşamın şekillenmesinde de aktörel bir role sahiptir (Bulut ve Dönmez, 2019, s.30). 6360 Sayılı Kanun ile Türkiye'de büyükşehirlerin tanımlanması ve buna bağlı olarak da büyükşehirlerin yapı ve işlevleri yeni bir şekil almıştır (Çalçalı, 2014, s.50). Kanunun oluşturulma gerekçeleri net bir şekilde belirtilmiştir. Küreselleşmeye bağlı olarak yönetim yaklaşımındaki değişmeler, etkin, verimli, saydam ve vatandaş odaklı bir yönetim anlayışı ile güçlü bir yerel yönetim yapısı oluşturmak bu gerekçelerden bazılarıdır (Kaymal, 2017, s.145). Yerel ölçek ve bunun hizmet kalitesine etkisi ile her türlü kaynakların israfı yine diğer gerekçeler arasında yer almaktadır (Oktay, 2016, s.81). 12 Kasım 2012 tarihinde kabul edilen 6360 Sayılı Kanun'a göre on üç ilde 
büyükşehir bu büyükşehirlerde yirmi altı ilçe kurulmasını ve bazı değişikleri içermektedir. Kanun kapsamında Hatay, Van, Trabzon, Kahramanmaraş, Mardin, Manisa, Muğla, Balıkesir, Tekirdağ, Malatya, Denizli, Aydın ve sonra Ordu ili de eklenerek bu büyükşehre dönüştürülmüştür (Oktay, 2016, s.82).

6360 sayılı Kanun'un getirdikleri şöyle özetlenebilir; (Zengin, 2014, s.102-103).

- "14 il belediyesi, büyükşsehir belediyesi yapılmış",

- "Sayısı otuza çıkan büyükşehir belediyelerinin sinırları, il mülki sinırlarıyla örtüştürülmüş; büyükşehir ilçe belediyelerinin sinırları da ilçe mülki sınırlarıyla çakıştıılmış",

- "Nüfusu 2000'in altında olan 559 belediye, köye dönüştürülmüş"

- "5747 sayll Kanun'dan itibaren iki kademeli olarak kurulan ve işleyen mevcut büyükşehir belediyesi modelinde, 2000 nüfus şartına bağhl kalmaksızın, bu ikili modelden dolayı yeni büyükşehir belediyesi stnırlart içinde kalan 1076 belde belediyesi ile 16500 köy tüzel kişiliğini kaybetmiş ve mahalleye dönüşmüş̧ür",

- "Büyükşehir belediyesi olmak için gerekli olan koşul, belediye nüfusunun 750000'i aşması yerine il nüfusunun 750000'in üzerinde olması biçiminde değiştirilmiş",

- "Yeni büyükşehir belediyesi olan 14 ilde, büyükşehir belediyesi kapsamında 25 yeni ilçe kurulmuş ve bağhllık değişiklikleri yapılmış, toplam büyükşehir ilçe belediyesi sayısı 143'ten 519'a çıkarılmış",

- "Kapatılarak mahalleye dönüştürülen belediye ve köylere ilişkin devir, tasfiye ve paylaştırma komisyonları öngörülmüş",

- "Otuz büyükşehir belediyesinde il özel idareleri kaldırılmış"

- "Il özel idareleri kaldırılan bu illerde, valiliklere bă̆gl Yatırım İzleme ve Koordinasyon Başkanlikları (YIKKOB) kurulmuştur".

\section{Hatay İlinin Genel Özellikleri}

Anadolu'nun yerleşim anlamında en eski yerlerinden biri olan Hatay'da, yaşam anlamında tarihi bulgular M.Ö. 100000'lere kadar dayanmaktadır. Elde edilen buluntular Hatay'ın birçok çağda yerleşim olduğunu ortaya koymaktadır. Hatay, 1. Dünya Savaşı́ndan sonra Fransızlar tarafından işgal edilmiştir. Fransızlar işgal sonrası Hatay'a 18 yıl egemen 
olmuşlardır. Hatay, 1938'de Hatay Devleti olarak hukuken kuruldu. Ancak, 7 Temmuz 1939'da Anavatana katılarak, Türkiye'nin bir ili konumuna geldi. Uzun yıllar il olan Hatay, 2012 yılında çıkarılan 6360 Sayılı Yasa büyükşehir oldu ve yeni kurulan ilçeler toplam on beş ilçeye sahip oldu. Tarım ve sanayiye dayalı bir ekonomisi mevcuttur. Suriye Krizinden sonra çok fazla sayıda sığınmacı göçüne maruz kalmıştır. İlin nüfusu 2020 yılı verilerine göre 1.659.320 kişidir (hatay.gov.tr).

\section{Araştırmanın Amacı ve Kapsamı}

Bu çalışma ile 2012 yılında çıkarılan 6360 Sayılı Yasa ve 2014 yılındaki mahalli idareler seçimi ile büyükşehir statüsüne geçen Hatay Büyükşehir Belediyesi'nin faaliyetleri ele alınmıştır. Hatay ilinde ikamet eden vatandaşlara uygulanacak bu anket ile büyükşehir belediyesinin çalışmaları istatiksel bir biçimde değerlendirilmiştir. Araştırmada uygulanacak anket için Hatay Mustafa Kemal Üniversitesi Sosyal ve Beşerî Bilimler Bilimsel Araştırma ve Yayın Etiği Kurulundan 17/11/2020 tarih ve E.52578 sayı ile izin alınmıştır.

\section{Araştırmanın Varsayımları}

$\mathrm{Bu}$ çalışmada ankete katılan vatandaşların olabildiğince gerçek düşünceleri elde edilmeye çalışılmıştır. Araştırmanın uygulanması esnasında ankete katılanlarda gönüllülük esası dikkate alınmıştır. Araştırmaya katılan katılımcıların anket sorularını doğru olarak anlayıp, buna göre cevap verdikleri varsayılmıştır.

\section{Araştırmanın Modeli}

$\mathrm{Bu}$ çalışmada tarama modeli esas alınmıştır. Ayrıca betimleyici bir araştırma özelliğine sahiptir. Çalışmada Hatay Büyükşehir Belediyesi'nin faaliyetleri hakkında hazırlanan anket soruları ilin on beş ilçesinde yaşayan vatandaşlara sorularak, veriler toplanarak, değerlendirilmesi yapılmıştır. 


\section{Evren ve Örneklem}

Araştırmanın evrenini Hatay ili oluşturmaktadır. Hatay ilinin ilçelerinin tamamında rastgele belirlenecek vatandaşlar da çalışmaya örneklem olmuştur. Ayrıca Hatay ilinde ikamet eden vatandaşların farklı kültür ve siyasi görüşe sahip olması, çalışmayı daha da zengin kılmaktadır.

\section{Araştırmanın Sınırlılıkları}

$\mathrm{Bu}$ araştırmada uygulanacak anket soruları sadece Hatay ili ve on beş ilçesi ile sınırlıdır. Bu açıdan elde edilen bulgular sadece Hatay iline özgüdür. Söz konusu anketin Hatay ilinde yaşayan vatandaşlara uygulandığı dikkate alındığında değerlendirme de yine bu il ile sinirlidır.

\section{Veri Toplama Yöntemi}

Veriler, anket yöntemi ile toplanmıştır. Çalışmanın anketi iki bölümden meydana gelmektedir. İlk bölümde demografi alanında sorular yer alırken ikinci bölümde çalışmanın temelini oluşturan Hatay Büyükşehir Belediyesinin faaliyetlerine ilişkin sorular bulunmaktadır.

\section{Kullanılan Ölçek}

Bu araştırmada 5’li(beşli) Likert ölçeği kullanılmıştır. Ölçek boyutlarının almış puanlar 1 ile 5 arasında değerlendirilmektedir. Dağılım aralığının hesaplanması amacıyla, Dağılım aralığı=En büyük değer- En küçük değer/ Derece sayısı formülü kullanılmıştır. Bu aralık 4 puanlık genişliğine sahiptir. $\mathrm{Bu}$ genişlik kendi arasında beş eşit genişliğe bölünerek, 1.00- 1.79 arası "çok düşük", 1.80- 2.59 arası "düşük", 2.603.39 "arası orta", 3.40-4.19 arası yüksek, 4.20-5.00 arası çok yüksek sınır değerleri olarak belirlenmiş ve çerçevede bulgular yorumlanmıştır. 


\section{Yöntem}

\section{Veri Toplama Aracı}

Çalışmada ölçeğin yapı geçerliliğinin belirlenmesi için açıklayıcı(açımlayıcı) "faktör analizi" yöntemi uygulanmıştır. Gerçekleştirilen "Barlett Testi" sonucunda $(\mathrm{p}=0.000<0.05)$ faktör analizine alınan değişkenler arasında ilişkinin varlığı tespit edilmiştir. Yapılan test sonucunda ise $(\mathrm{KMO}=0.798>0,60)$ örnek büyüklüğünün faktör analizinin uygulanması için yeterli olduğu tespit edilmiştir. Faktör analizi uygulamasında "Varimax Yöntemi" seçilerek faktörler arasındaki ilişki yapısının aynı kalması sağlanmıştır. Faktör analizi sonucunda değişkenler, toplam varyansı \%47.248 olan 2 faktör altında toplanmıştır. Faktör yükü düşük olan 2 madde ölçekten çıkartılmıştır. Algı ölçeğinde yer alan 13 maddenin güvenirliğini ortaya koymak için iç tutarlılık katsayısı olan "Cronbach Alpha" hesaplanmıştır. Ölçeğin genel güvenirliği hesaplama sonucu alpha=0.773 olarak, yüksek çıkmıştır. Bu oran ile çalışmanın güvenirliğine ilişkin bulunan alpha ve açıklanan varyans değerine göre algı ölçeğinin geçerli ve güvenilir bir araç olduğu anlaşılmıştır. Ölçeğe ait oluşan faktör yapısı aşağıda görülmektedir.

Tablo 2. Alfa Kaysayı Güven Aralı̆̆ı

\begin{tabular}{|c|c|}
\hline ALFA (CRONBACH) KATSAYI & YORUM \\
\hline $0,00-0,40$ & Güvenilir Değil \\
\hline $0,40-0,60$ & Güvenirliği Düşük \\
\hline $0,60-0,80$ & Oldukça Güvenilir \\
\hline $0,80-1,00$ & Yüksek Derece Güvenilir \\
\hline
\end{tabular}

Kayış, 2010, s.403.

Ölçekteki faktörlerin puanları hesaplanırken faktördeki maddelerin değerleri toplandıktan sonra madde sayısına bölünerek (aritmetik ortalama) faktör puanları elde edilmiştir. 
Tablo 3. Algı Ölçeği Faktör Yapısı

\begin{tabular}{|c|c|}
\hline Boyut & $\begin{array}{l}\text { Faktör } \\
\text { Yükü }\end{array}$ \\
\hline Hizmet (Özdeğer=3,826; Açıklanan Varyans=25,678; Alpha=0,760) & \\
\hline $\begin{array}{l}\text { Hatay İlinin Büyükşehir Olması İle Beraber Başta Trafik Olmak Üzere, Su, } \\
\text { Kanalizasyon ve Yeşil Alan Gibi Konularda Sorunlar Artmaya Başlamıştır* }\end{array}$ & 0,765 \\
\hline $\begin{array}{l}\text { Hatay İlinin Büyükşehir Statüsüne Geçesiyle Hem Toplu Taşıma Sorunu Hem De } \\
\text { Ulaşım Ücretleri Artmıştır* }\end{array}$ & 0,724 \\
\hline $\begin{array}{l}\text { Hatay İlinin Büyükşehir Olması Sonucu Su Faturalarında Ciddi Bir Artış Meydana } \\
\text { Gelmiştir* }\end{array}$ & 0,713 \\
\hline $\begin{array}{l}\text { Hatay Büyükşehir Belediyesinde Bazı Yerel Hizmetlerin İlçe Belediyelerine } \\
\text { Devredilmemesi Sonucu Zarar Gören Yerel Halk Olmaktadır* }\end{array}$ & 0,680 \\
\hline $\begin{array}{l}\text { Hatay İlinin Büyükşehir Olmasıyla Beraber İlçe Belediyelerinin Hizmet Alanı ve } \\
\text { Bütçesi Daralmıştır* }\end{array}$ & 0,673 \\
\hline $\begin{array}{l}\text { Hatay İli Büyükşehir Olduktan Sonra Merkez İle İlçeler Arasında Hizmet Sorunu } \\
\text { Yaşanmaktadır* }\end{array}$ & 0,517 \\
\hline $\begin{array}{l}\text { Hatay İli Alt Yapı, Ulaşım, Ölçek vb. Nedenlerden Dolayı Büyükşsehir Olmaya Uygun } \\
\text { Bir İl Değildir* }\end{array}$ & 0,480 \\
\hline $\begin{array}{l}\text { Hatay İlinin Büyükşehir Olması ve Hatay'da Ciddi Sayıda Suriyeli Sığınmacının } \\
\text { Olması Büyükşehrin İş Yükünü Arttırmaktadır* } \\
\text { Yönetim (Özdeğer=2,316; Açılanan Varyans=21,570; Alpha=0,736) }\end{array}$ & 0,445 \\
\hline Hatay İlinin Büyükşehir Olması İle Kaynak İsrafının Önüne Geçilmiştir & 0,734 \\
\hline $\begin{array}{l}\text { Hatay İlinin Büyükşehir Olması Yerel Kamu Hizmetlerinin Tüm İlçelerde Adil Bir } \\
\text { Şekilde Sunulmasını Sağlamaktadır }\end{array}$ & 0,728 \\
\hline Hatay İlinin Büyükşehir Statüsüne Geçmesiyle Beraber Personel, Başkanlık, Müdürlük & \\
\hline $\begin{array}{l}\text { ve Kurumsal Kimlik Noktasında Gelişimini Doğru ve Objektif Bir Şekilde } \\
\text { Gerçekleştirmiştir }\end{array}$ & 0,724 \\
\hline Hatay İlinin Büyükşehir Statüsüne Geçirilmesi Doğru Bir Karardır & 0,593 \\
\hline $\begin{array}{l}\text { Hatay Büyükşehir Belediyesi Bütçesi ve Personeline Bağlı Olarak Görev ve } \\
\text { Sorumluluklarını Yerine Getirmek İçin Yoğun Çaba Sarf Etmektedir } \\
\text { Toplam Varyans=\%47.248; Genel Güvenirlik (Alpha)=0.773 }\end{array}$ & 0,558 \\
\hline
\end{tabular}

\section{Verilerin İstatistiksel Analizi}

Araştırmada elde edilen veriler SPSS (Statistical Package for Social Sciences) for Windows 22.0 programı kullanılarak analiz edilmiştir. Verilerin değerlendirilmesinde tanımlayıcı istatistiksel yöntemleri olarak sayı, yüzde, ortalama, standart sapma kullanılmıştır. İki bağımsız grup arasında niceliksel sürekli verilerin karşılaştırılmasında t-testi, ikiden fazla bağımsız grup arasında niceliksel sürekli verilerin karşılaştırılmasında Tek yönlü (One way) Anova testi kullanılmıştır. 
Anova testi sonrasında farklılıkları belirlemek üzere tamamlayıcı posthoc analizi olarak Scheffe testi kullanılmıştır.

\section{Bulgular ve Yorumlar}

Çalışmanın bu bölümünde araştırmaya katılan katılımcılardan alınan cevaplar sonucu elde edilen bulgulara bağlı olarak açıklama ve yorumlar yapılmıştır.

Tablo 4. Tanımlayıcı Özellikler

\begin{tabular}{lll}
\hline Gruplar & Frekans(n) & Yüzde (\%) \\
\hline Cinsiyet & 194 & \\
Erkek & 202 & 49,0 \\
Kadın & & 51,0 \\
Medeni Durum & 291 & \\
Bekar & 105 & 73,5 \\
Evli & & 26,5 \\
Yaş & 288 & \\
18-30 & 80 & 72,7 \\
31-45 & 25 & 20,2 \\
46-60 & 3 & 6,3 \\
60 Ve Sonrasi & & 0,8 \\
Eğitim Durumu & 11 & \\
Doktora & 6 & 2,8 \\
İkokul & 73 & 1,5 \\
Lisans & 48 & 18,4 \\
Lise & 1 & 12,1 \\
Okur-yazar Değil & 7 & 0,3 \\
Ortaokul & 220 & 1,8 \\
Önlisans & 30 & 55,6 \\
Yüksek Lisans & & 7,6 \\
Aylık Gelir & 265 & 66,9 \\
0-2500 Tl & 8 & 2,0 \\
10000 Ve Üzeri & 62 & 15,7 \\
2501-5000tl & 44 & 11,1 \\
5001-7500tl & 17 & 4,3 \\
7501-10000tl & &
\end{tabular}

Katılanlar cinsiyete göre 194'ü (\%49,0) Erkek, 202'si (\%51,0) kadın olarak dağılmaktadır.

Katılanlar medeni duruma göre 291'i (\%73,5) Bekar, 105'i (\%26,5) Evli olarak dağılmaktadır. 
Katılanlar yaşa göre 288'i (\%72,7) 18-30, 80'i (\%20,2) 31-45, 25'i (\%6,3) 46-60, 3 'ü $(\% 0,8) 60$ ve sonrası olarak dağılmaktadır.

Katılanlar eğitim durumuna göre 11'i $(\% 2,8)$ Doktora, 6's1 (\%1,5) İlkokul, 73'ü (\%18,4) Lisans, 48'i (\%12,1) Lise, 1'i (\%0,3) Okur-Yazar değil, 7'si $(\% 1,8)$ Ortaokul, 220'si $(\% 55,6)$ Önlisans, 30'u $(\% 7,6)$ Yüksek Lisans olarak dağılmaktadır.

Katılanlar aylık gelire göre 265'i (\%66,9) 0-2500 tl, 8'i (\%2,0) 10000 ve üzeri, 62'si (\%15,7) 2501-5000tl, 44'ü (\%11,1) 5001-7500tl, 17'si (\%4,3) 7501-10000tl olarak dağılmaktadır.

Araştırmaya katılan katılımcıların hizmet alanındaki ifadelere vermiş olduğu cevapların dağılımı aşağıdaki gibidir.

Araştırmaya katılan katılanların hizmet ile ilgili ifadelere verdiği cevaplar incelendiğinde;

“Hatay İlinin Büyükşehir Olması ile Beraber Başta Trafik Olmak Üzere, Su, Kanalizasyon Ve Yeşil Alan Gibi Konularda Sorunlar Artmaya Başlamıştır*" ifadesine katılanların, \%40,4'ü (n=160) hiç katılmıyorum, \%19,4'ü (n=77) katılmıorum, \%22,0'1 ( $\mathrm{n}=87)$ kararsızım, \%7,8'i (n=31) katılıyorum, $\% 10,4$ 'ü $(\mathrm{n}=41)$ tamamen katılıyorum yanıtını vermiştir. Katılanların "hatay ilinin büyükşehir olması ile beraber başta trafik olmak üzere, su, kanalizasyon ve yeşil alan gibi konularda sorunlar artmaya başlamıştır*" ifadesine zayıf $(\bar{x}=2,283)$ düzeyde katıldıkları saptanmıştır.

"Hatay İlinin Büyükşehir Statüsüne Geçesiyle Hem Toplu Taşıma Sorunu Hem De Ulaşım Ücretleri Artmıştır" if ifadesine katılanların, \%55,6's1 (n=220) hiç katılmıyorum, \%14,9'u (n=59) katılmıyorum, \%18,4'ü (n=73) kararsızım, \%5,3'ü $(\mathrm{n}=21)$ katıliyorum, \%5,8'i $(\mathrm{n}=23)$ tamamen katılıyorum yanıtını vermiştir. Katılanların "hatay ilinin büyükşehir statüsüne geçesiyle hem toplu taşıma sorunu hem de ulaşım ücretleri artmıştır*" ifadesine zayıf $(\bar{x}=1,909)$ düzeyde katıldıkları saptanmıştır.

vermiştir. Katılanların "hatay ilinin büyükşehir olması sonucu su faturalarında ciddi bir artış meydana gelmiştir*" ifadesine zayıf $(\bar{x}=2,091)$ düzeyde katıldıkları saptanmıştır. 


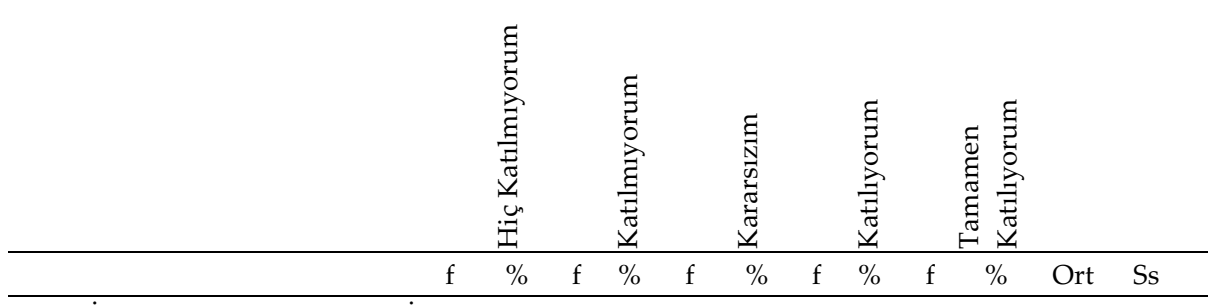

Hatay İlinin Büyükşehir Olması İle Beraber Başta Trafik Olmak Üzere,

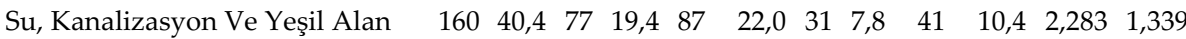
Gibi Konularda Sorunlar Artmaya

Başlamıştır*

Hatay İlinin Büyükşehir Statüsüne

Geçesiyle Hem Toplu Taşıma

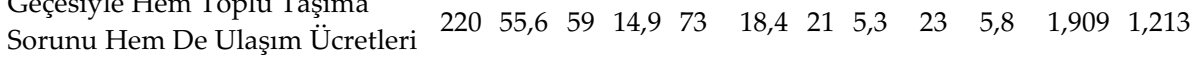

Artmıştır*

Hatay İlinin Büyükşehir Olması

Sonucu Su Faturalarında Ciddi Bir $180 \quad 45,5 \quad 71 \quad 17,9 \quad 96 \quad 24,2 \quad 27 \quad 6,8 \quad 22 \quad 5,6 \quad 2,091 \quad 1,210$

Artış Meydana Gelmiştir*

Hatay Büyükşehir Belediyesinde

Bazı Yerel Hizmetlerin İlçe

$\begin{array}{llllllllllll}\text { Belediyelerine Devredilmemesi } \quad 189 & 47,7 & 66 & 16,7 & 71 & 17,9 & 44 & 8,6 & 36 & 9,1 & 2,146 & 1,342\end{array}$

Sonucu Zarar Gören Yerel Halk

Olmaktadır*

Hatay İlinin Büyükşehir Olmasıyla

Beraber İlçe Belediyelerinin

Hizmet Alanı Ve Bütçesi

$\begin{array}{llllllllllll}117 & 29,5 & 75 & 18,9 & 125 & 31,6 & 44 & 11,1 & 35 & 8,8 & 2,508 & 1,264\end{array}$

Daralmıştır*

Hatay İli Büyükşehir Olduktan

Sonra Merkez İle İlçeler Arasında $146 \quad 36,9 \quad 57 \quad \begin{array}{llllll}14,4 & 90 & 22,7 & 54 & 13,6 & 49\end{array}$ 12,4 2,503 1,417

Hizmet Sorunu Yaşanmaktadır*

Hatay İli Alt Yapı, Ulaşım, Ölçek

$\mathrm{Vb}$ Nedenlerden Dolayı

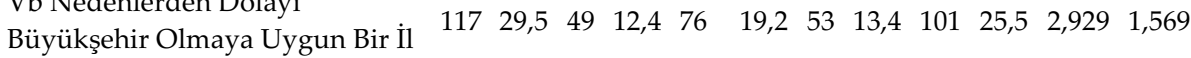

Değildir*

Hatay İlinin Büyükşehir Olması

Ve Hatay'da Ciddi Sayıda Suriyeli

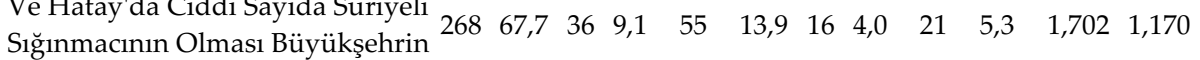

İş Yükünü Arttırmaktadır*

“Hatay İlinin Büyükşehir Olması Sonucu Su Faturalarında Ciddi Bir Artış Meydana Gelmiştir*" ifadesine katılanların, \%45,5'i (n=180) hiç katılmıyorum, \%17,9'u (n=71) katılmıyorum, \%24,2'si (n=96) kararsızım, 
\%6,8'i (n=27) katılıyorum, \%5,6's1 (n=22) tamamen katılıyorum yanıtını "Hatay Büyükşehir Belediyesinde Bazı Yerel Hizmetlerin İlçe Belediyelerine Devredilmemesi Sonucu Zarar Gören Yerel Halk Olmaktadır" ifadesine katılanların, \%47,7'si (n=189) hiç katılmıyorum, \%16,7'si (n=66) katılmiyorum, \%17,9'u (n=71) kararsızım, \%8,6'sı (n=34) katılıyorum, $\% 9,1$ 'i $(\mathrm{n}=36)$ tamamen katılıyorum yanıtını vermiştir. Katılanların "hatay büyükşehir belediyesinde bazı yerel hizmetlerin ilçe belediyelerine devredilmemesi sonucu zarar gören yerel halk olmaktadır ${ }^{* \prime \prime}$ ifadesine zayıf $(\overline{x=2,146)}$ düzeyde katıldıkları saptanmıştır.

"Hatay İlinin Büyükşehir Olmasıyla Beraber İlçe Belediyelerinin Hizmet Alanı Ve Bütçesi Daralmıştı*" ifadesine katılanların, \%29,5'i (n=117) hiç katılmiyorum, \%18,9'u (n=75) katılmıyorum, \%31,6'sı (n=125) kararsızım, \%11,1'i (n=44) katılıyorum, \%8,8'i (n=35) tamamen katılıyorum yanıtını vermiştir. Katılanların "hatay ilinin büyükşehir olmasıyla beraber ilçe belediyelerinin hizmet alanı ve bütçesi daralmıştı*" ifadesine zayıf $(\bar{x}=2,508)$ düzeyde katıldıkları saptanmıştır.

"Hatay İli Büyükşehir Olduktan Sonra Merkez İle İlçeler Arasında Hizmet Sorunu Yaşanmaktadır" if" ifadesine katılanların, \%36,9'u (n=146) hiç katılmıyorum, \%14,4'ü ( $\mathrm{n}=57)$ katılmıyorum, \%22,7'si (n=90) kararsızım, \%13,6'sı (n=54) katıliyorum, \%12,4'ü $(n=49)$ tamamen katıliyorum yanıtını vermiştir. Katılanların "hatay ili büyükşehir olduktan sonra merkez ile ilçeler arasında hizmet sorunu yaşanmaktadır*" ifadesine zayıf $\left(\bar{x}^{\bar{x}}=2,503\right)$ düzeyde katıldıkları saptanmıştır.

"Hatay İli Alt Yapı, Ulaşım, Ölçek Vb Nedenlerden Dolayı Büyükşehir Olmaya Uygun Bir Il Değildir*" ifadesine katılanların, \%29,5'i (n=117) hiç katılmıyorum, \%12,4'ü (n=49) katılmıyorum, \%19,2'si (n=76) kararsızım, \%13,4'ü (n=53) katıliyorum, \%25,5'i (n=101) tamamen katıliyorum yanıtını vermiştir. Katılanların "hatay ili alt yapı, ulaşım, ölçek vb nedenlerden dolayı büyükşehir olmaya uygun bir il değildir*" ifadesine orta $(\bar{x}=2,929)$ düzeyde katıldıkları saptanmıştır.

"Hatay İlinin Büyükşehir Olması Ve Hatay'da Ciddi Sayıda Suriyeli Sı ̆̆ınmacının Olması Büyükşehrin İş Yükünü Arttırmaktadır" ifadesine katılanların, \%67,7'si (n=268) hiç katılmıyorum, \%9,1'i (n=36) katılmıyorum, \%13,9'u (n=55) kararsızım, \%4,0'ı (n=16) katılıyorum, $\% 5,3$ '̈̈ (n=21) tamamen katıllyorum yanıtını vermiştir. Katılanların "hatay ilinin büyükşehir olması ve hatay'da ciddi sayıda suriyeli 
sığınmacının olması büyükşehrin iş yükünü arttırmaktadır»" ifadesine çok zayıf $(\bar{x}=1,702)$ düzeyde katıldıkları saptanmıştır.

Araştırmaya katılanların, yönetim başlı̆̆ındaki ifadelere verdikleri cevapların dağılımları aşağıdaki gibidir:

Tablo 6. Katılanların Yönetim ile İlgili İfadelere Verdiği Cevapların Dă̆ılımlarn

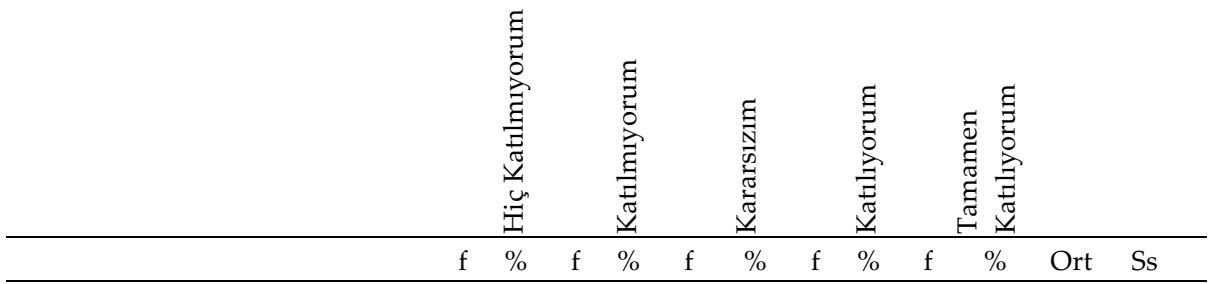

Hatay İlinin Büyükşehir Olması

ile Kaynak İsrafının Önüne

$\begin{array}{llllllllllll}41 & 17,4 & 44 & 18,7 & 85 & 36,2 & 35 & 14,9 & 30 & 12,8 & 2,868 & 1,239\end{array}$

Geçilmiştir

Hatay İlinin Büyükşehir Olması

Yerel Kamu Hizmetlerinin Tüm

İlçelerde Adil Bir Şekilde

$\begin{array}{llllllllllll}95 & 24,0 & 63 & 15,9 & 116 & 29,3 & 57 & 14,4 & 65 & 16,4 & 2,833 & 1,377\end{array}$

Sunulmasını Sağlamaktadır

Hatay İlinin Büyükşehir Statüsüne

Geçmesiyle Beraber Personel,

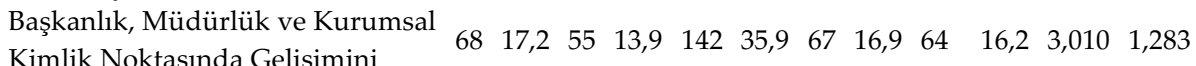

Kimlik Noktasında Gelişimini

Doğru ve Objektif Bir Şekilde

Gerçekleştirmiştir

Hatay İlinin Büyükşehir Statüsüne

Geçirilmesi Doğru Bir Karardır

$\begin{array}{lllllllllllll}66 & 16,7 & 28 & 7,1 & 75 & 18,9 & 58 & 14,6 & 169 & 42,7 & 3,596 & 1,497\end{array}$

Hatay Büyükşehir Belediyesi

Bütçesi ve Personeline Bağlı

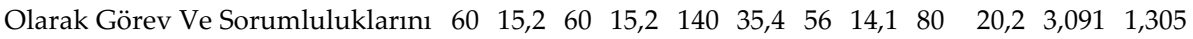

Yerine Getirmek İçin Yoğun Çaba

Sarf Etmektedir

Araştırmaya katılan katılanların yönetim ile ilgili ifadelere verdiği cevaplar incelendiğinde;

"Hatay İlinin Büyükşehir Olması ile Kaynak İsrafının Önüne Geçilmiştir" ifadesine katılanların, \%17,4'ü ( $\mathrm{n}=41)$ hiç katılmıyorum, \%18,7'si (n=44) katılmiyorum, \%36,2'si ( $\mathrm{n}=85)$ kararsızım, \%14,9'u (n=35) katılıyorum, $\% 12,8$ 'i $(n=30)$ ise tamamen katılıyorum cevabını vermiştir. Katılanların 
"hatay ilinin büyükşehir olması ile kaynak israfının önüne geçilmiştir" ifadesine orta $(\overline{\mathrm{x}}=2,868)$ düzeyde katıldıkları saptanmıştır.

“Hatay İlinin Büyükşehir Olması Yerel Kamu Hizmetlerinin Tüm İlçelerde Adil Bir Şekilde Sunulmasını Sağlamaktadır" ifadesine katılanların, \%24,0'1 (n=95) hiç katılmıyorum, \%15,9'u (n=63) katılmıyorum, \%29,3'ü (n=116) kararsızım, \%14,4'ü $(n=57)$ katılıyorum, \%16,4'ü $(n=65)$ tamamen katılıyorum yanıtını vermiştir. Katılanların "hatay ilinin büyükşehir olması yerel kamu hizmetlerinin tüm ilçelerde adil bir şekilde sunulmasını sağlamaktadır" ifadesine orta $(\bar{x}=2,833)$ düzeyde katıldıkları saptanmiştır.

"Hatay Illinin Büyükşehir Statüsüne Geçmesiyle Beraber Personel, Başkanlık, Müdürlük Ve Kurumsal Kimlik Noktasında Gelişimini Doğru Ve Objektif Bir Şekilde Gerçekleştirmiştir" ifadesine katılanların, \%17,2'si $(\mathrm{n}=68)$ hiç katılmıyorum, \%13,9'u (n=55) katılmıyorum, \%35,9'u (n=142) kararsızım, \%16,9'u (n=67) katıliyorum, \%16,2'si (n=64) tamamen katılıyorum yanıtını vermiştir. Katılanların "hatay ilinin büyükşehir statüsüne geçmesiyle beraber personel, başkanlık, müdürlük ve kurumsal kimlik noktasında gelişimini doğru ve objektif bir şekilde gerçekleştirmiştir" ifadesine orta $(\overline{\mathrm{x}}=3,010)$ düzeyde katıldıkları saptanmıştır.

"Hatay İlinin Büyükşehir Statüsüne Geçirilmesi Doğru Bir Karardır" ifadesine katılanların, \%16,7'si (n=66) hiç katılmıyorum, \%7,1'i (n=28) katılmiyorum, \%18,9'u (n=75) kararsızım, \%14,6'sı (n=58) katıliyorum, \%42,7'si ( $\mathrm{n}=169)$ tamamen katılıyorum yanıtını vermiştir. Katılanların "hatay ilinin büyükşehir statüsüne geçirilmesi doğru bir karardır" ifadesine yüksek $(\bar{x}=3,596)$ düzeyde katıldıkları saptanmıştır.

"Hatay Büyükşehir Belediyesi Bütçesi Ve Personeline Bağhl Olarak Görev Ve Sorumluluklarım Yerine Getirmek İçin Yoğun Çaba Sarf Etmektedir" ifadesine katılanların, \%15,2'si (n=60) hiç katılmıyorum, \%15,2'si $\quad(n=60)$ katılmiyorum, \%35,4'ü (n=140) kararsızım, \%14,1'i (n=56) katılıyorum, $\% 20,2$ 'si $(n=80)$ tamamen katılıyorum yanıtını vermiştir. Katılanların "hatay büyükşehir belediyesi bütçesi ve personeline bağlı olarak görev ve sorumluluklarını yerine getirmek için yoğun çaba sarf etmektedir" ifadesine orta $(\bar{x}=3,091)$ düzeyde katıldıkları saptanmıştır. 
Tablo 7. Algı Puan Ortalamaları

\begin{tabular}{llllll}
\hline & $\mathrm{N}$ & Ort & Ss & Min. & Max. \\
\hline Hizmet & 396 & 2,259 & 0,807 & 1,000 & 5,000 \\
Yönetim & 396 & 3,109 & 0,961 & 1,000 & 5,000 \\
Alg1 Genel & 396 & 2,566 & 0,704 & 1,000 & 4,750 \\
\hline
\end{tabular}

Katılanların "hizmet" ortalaması zayıf 2,259 $\pm 0,807$ (Min=1; Maks=5), "yönetim" ortalaması orta 3,109 $\pm 0,961$ (Min=1; Maks=5), "alg1 genel" ortalaması zayıf 2,566 $\pm 0,704$ (Min=1; Maks=4.75) olarak saptanmıştır.

Tablo 8. Algının Tanımlayıcı Özelliklerle Farklılaşma Durum Tablosu

\begin{tabular}{|c|c|c|c|c|}
\hline Demografik Özellikler & $\mathbf{n}$ & Hizmet & Yönetim & Alg1 Genel \\
\hline Cinsiyet & & Ort \pm SS & Ort \pm SS & Ort \pm SS \\
\hline Erkek & 194 & $2,340 \pm 0,867$ & $3,057 \pm 1,019$ & $2,600 \pm 0,759$ \\
\hline Kadın & 202 & $2,181 \pm 0,740$ & $3,159 \pm 0,902$ & $2,533 \pm 0,647$ \\
\hline$t=$ & & 1,973 & $-1,055$ & 0,949 \\
\hline $\mathrm{p}=$ & & 0,050 & 0,292 & 0,343 \\
\hline Medeni Durum & & Ort \pm SS & Ort \pm SS & Ort \pm SS \\
\hline Evli & 105 & $2,116 \pm 0,832$ & $2,830 \pm 0,952$ & $2,375 \pm 0,727$ \\
\hline Bekar & 291 & $2,311 \pm 0,794$ & $3,210 \pm 0,946$ & $2,635 \pm 0,683$ \\
\hline$t=$ & & $-2,132$ & $-3,519$ & $-3,287$ \\
\hline $\mathrm{p}=$ & & 0,034 & 0,000 & 0,001 \\
\hline Yaş & & Ort \pm SS & Ort \pm SS & Ort \pm SS \\
\hline $18-30$ & 288 & $2,292 \pm 0,770$ & $3,249 \pm 0,935$ & $2,637 \pm 0,667$ \\
\hline $31-45$ & 80 & $2,173 \pm 0,935$ & $2,781 \pm 0,915$ & $2,395 \pm 0,778$ \\
\hline 46 Ve Üzeri & 28 & $2,165 \pm 0,798$ & $2,609 \pm 0,989$ & $2,319 \pm 0,736$ \\
\hline $\mathrm{F}=$ & & 0,873 & 12,129 & 5,680 \\
\hline$p=$ & & 0,418 & 0,000 & 0,004 \\
\hline PostHoc $=$ & & & $1>2,1>3(p<0.05)$ & $1>2,1>3(p<0.05)$ \\
\hline Eğitim Durumu & & Ort \pm SS & Ort \pm SS & Ort \pm SS \\
\hline Lise Ve Alt1 & 62 & $2,224 \pm 0,854$ & $3,065 \pm 1,010$ & $2,516 \pm 0,696$ \\
\hline Önlisans & 220 & $2,305 \pm 0,809$ & $3,181 \pm 0,955$ & $2,622 \pm 0,707$ \\
\hline Lisans & 73 & $2,303 \pm 0,805$ & $3,082 \pm 0,982$ & $2,578 \pm 0,742$ \\
\hline Lisansüstü & 41 & $1,988 \pm 0,694$ & $2,839 \pm 0,856$ & $2,315 \pm 0,584$ \\
\hline $\mathrm{F}=$ & & 1,900 & 1,556 & 2,342 \\
\hline $\mathrm{p}=$ & & 0,129 & 0,200 & 0,073 \\
\hline Aylık Gelir & & Ort \pm SS & Ort \pm SS & Ort \pm SS \\
\hline $0-2500 \mathrm{Tl}$ & 265 & $2,298 \pm 0,776$ & $3,245 \pm 0,936$ & $2,640 \pm 0,665$ \\
\hline 2501-5000tl & 62 & $2,169 \pm 0,842$ & $2,884 \pm 0,953$ & $2,419 \pm 0,765$ \\
\hline 5001-7500tl & 44 & $2,332 \pm 0,897$ & $2,814 \pm 0,805$ & $2,517 \pm 0,790$ \\
\hline 7500 Tl Üzeri & 25 & $1,935 \pm 0,840$ & $2,744 \pm 1,208$ & $2,225 \pm 0,666$ \\
\hline $\mathrm{F}=$ & & 1,939 & 5,688 & 4,011 \\
\hline $\mathrm{p}=$ & & 0,123 & 0,001 & 0,008 \\
\hline PostHoc $=$ & & & $1>2,1>3,1>4(p<0.05)$ & $1>2,1>4(\mathrm{p}<0.05)$ \\
\hline
\end{tabular}


Cinsiyet: Erkeklerin hizmet puanları $(\mathrm{x}=2,340)$, kadınların hizmet puanlarından $(\mathrm{x}=2,181)$ yüksek bulunmuştur $(\mathrm{t}=1,973 ; \mathrm{p}=0.05<0.05)$. Katılanların yönetim ve algı genel puanları cinsiyet değişkenine göre anlamlı bir farklılık göstermemektedir(p>0.05).

Medeni Durum: Evlilerin hizmet puanları $(\mathrm{x}=2,116)$, bekarların hizmet puanlarından $(\mathrm{x}=2,311)$ düşük bulunmuştur $(\mathrm{t}=-2,132$; $\mathrm{p}=0.034<0.05)$.

Evlilerin yönetim puanları $(x=2,830)$, bekarların yönetim puanlarından $(x=3,210)$ düşük bulunmuştur $(\mathrm{t}=-3,519 ; \mathrm{p}=0<0.05)$.

Evlilerin alg1 genel puanları $(x=2,375)$, bekarların alg1 genel puanlarından $(x=2,635)$ düşük bulunmuştur $(t=-3,287 ; p=0.001<0.05)$.

Yaş: Katılanların yönetim puanları yaş değişkenine göre anlamlı farklılık göstermektedir $(\mathrm{F}=12,129 ; \mathrm{p}=0<0.05)$. Farkın nedeni Yaş 18-30 olanların yönetim puanlarının yaş 31-45 olanların yönetim puanlarından yüksek olmasıdır $(\mathrm{p}<0.05)$. Yaş 18-30 olanların yönetim puanlarının yaş 46 ve üzeri olanların yönetim puanlarından yüksek olmasıdır $(\mathrm{p}<0.05)$.

Katılanların algı genel puanları yaş değişkenine göre anlamlı farklılık göstermektedir $(\mathrm{F}=5,680 ; \mathrm{p}=0.004<0.05)$. Farkın nedeni Yaş 18-30 olanların algı genel puanlarının yaş 31-45 olanların algı genel puanlarından yüksek olmasıdır $(\mathrm{p}<0.05)$. Yaş 18-30 olanların algı genel puanlarının yaş 46 ve üzeri olanların algı genel puanlarından yüksek olmasıdır $(\mathrm{p}<0.05)$.

Katılanların, hizmet puanları yaş değişkenine göre de anlamlı bir farkl1lık göstermemektedir( $\mathrm{p}>0.05)$.

Eğitim Durumu: Çalışmaya katılanların hizmet, yönetim ve algı genel puanları da eğitim durumu değişkenine göre anlamlı bir farklılık göstermemektedir( $\mathrm{p}>0.05)$.

Aylık Gelir: Katılanların yönetim puanları aylık gelir değişkenine göre anlamlı farklılık göstermektedir $(\mathrm{F}=5,688 ; \mathrm{p}=0.001<0.05)$. Farkın nedeni Aylık gelir 0-2500 tl olanların yönetim puanlarının aylık gelir 2501-5000tl olanların yönetim puanlarından yüksek olmasıdır( $\mathrm{p}<0.05)$. Aylık gelir 02500 tl olanların yönetim puanlarının aylık gelir 5001-7500tl olanların yönetim puanlarından yüksek olmasıdır(p<0.05). Aylık gelir $0-2500 \mathrm{tl}$ 
olanların yönetim puanlarının aylık gelir 7500 tl üzeri olanların yönetim puanlarından yüksek olmasıdır $(\mathrm{p}<0.05)$.

Katılanların algı genel puanları aylık gelir değişkenine göre anlamlı farklılık göstermektedir $(\mathrm{F}=4,011 ; \mathrm{p}=0.008<0.05)$. Farkın nedeni Aylık gelir 0-2500 tl olanların alg1 genel puanlarının aylık gelir 2501-5000tl olanların algı genel puanlarından yüksek olmasıdır( $\mathrm{p}<0.05)$. Aylık gelir 0-2500 tl olanların alg1 genel puanlarının aylık gelir 7500 tl üzeri olanların algı genel puanlarından yüksek olmasıdır $(\mathrm{p}<0.05)$.

Katılanların, hizmet puanları yine aylık gelir değişkenine göre de anlamlı bir farklılık göstermemektedir( $\mathrm{p}>0.05)$.

\section{Sonuç}

Büyükşehir belediye yönetimlerinin dayanağı yasal düzenlemelerdir. Ülkemizde 1982 Anayasasının 127/3. Maddesine göre büyük yerleşim yerleri için özel yönetim birimleri oluşturulabilir ifadesine bağlı olarak ülkemizde büyükşehir belediye yönetimleri ilk defa 1984 yılının Mart ayında uygulanmaya başlanmıştır. İlk olarak İstanbul, Ankara ve İzmir vilayetleri büyükşehir statüsüne geçmiş ve daha sonraki tarihsel süreçte bu vilayetlerin sayısı artmaya başlamıştır. Özellikle 1950 yılı sonrası tarımda makineleşme ve kırdan kente göç süreci beraberinde büyük yerleşimlerin oluşmana sebep olmuştur. Bu büyük yerleşimlere bağlı olarak büyükşehirlerin önemi ve gerekliliği ortaya çıkmıştır.

2012 yılında çıkarılan ve 2014 mahalli idare seçimleri ile yürürlüğe giren 6360 Sayılı Yasa büyükşehir ve yerel yönetimler konusunda geniş düzenlemeler içermektedir. 6360 Sayılı Yasanın getirdiği yeniliklerden bazıları şunlardır:

1. Önce on üç vilayet ardından Ordu ile beraber toplamda 14 vilayet büyükşehir statüsüne geçmiş ve ülkemizdeki büyükşehir belediye sayısı otuz olmuştur.

2. Büyükşehir olan illerde belde belediyeleri ve köylerin tüzel kişiliği kaldırılarak, mahalleye dönüştürülmüştür.

3. Yeni büyükşehir olan vilayetlerde yeni ilçeler kurulmuştur.

4. Büyükşehir olan bu vilayetlerde yine İl Özel İdareleri kapatılmış ve onun yerine Yatırım İzleme ve Koordinasyon Başkanlıkları kurulmuştur. 
5. Büyükşehir olmadaki tek kriter nüfus (750 bin) olmuştur.

6360 Sayılı Yasa'nın ortaya çıkmasında özellikle iki noktada durulmaktadır. Yani büyükşehirlerle ilgili olarak iki temel gerekçeye vurgu yapılmaktadır. Bu gerekçelere bakıldığında küreselleşmeye bağlı olarak yönetim yaklaşımındaki değişmeler, etkin, verimli, saydam ve vatandaş odaklı bir yönetim anlayışı ile güçlü bir yerel yönetim yapısı oluşturmak ve yerel ölçek ile bunun hizmet kalitesine etkisi ile her türlü kaynakların israfının önlenmesi, kaynakların doğru kullanılması yer almaktadır.

Hatay ölçeği esas alınarak yapılan uygulamada Hatay ilinin büyükşehir olmasının ve faaliyetlerinin yer halk algısı nezdinde bir değerlendirilmesi yapılmıştır. Hazırlanan ve Hatay Mustafa Kemal Üniversitesi Sosyal ve Beşerî Bilimler Bilimsel Araştırma ve Yayın Etiği Kurulundan izin alınan anket soruları İlin tüm ilçelerinde uygulanmış ve alınan cevaplar SPSS programı ile analiz edilmiştir. Çalışma neticesinde alınan sonuçlar ve vurgu yapılması gereken noktalar şunlardır:

1. Hatay Büyükşehir Belediyesinin çalışmaları yerel halkın algisında "hizmet ve yönetim" ölçeğinde ortaya konulmuştur.

2. Çalışmanın güvenirliliği 0.773 ile oldukça güvenilir çıkmıştır.

3. Çalışmaya katılan yerel halkın "hizmet" ortalaması zayıf "yönetim" ortalaması orta "alg1 genel" ortalaması zayıf olarak saptanmıştır.

4. Cinsiyet açısından erkeklerin hizmet puanları, kadınların hizmet puanlarından yüksek bulunmuştur. Katılanların yönetim ve alg1 genel puanları cinsiyet değişkeni bağlamında anlamlı bir farklılık göstermemektedir.

5. Medeni durum açısından evlilerin hizmet puanları, bekarların hizmet puanlarından düşük bulunmuştur. Evlilerin yönetim puanları, bekarların yönetim puanlarından düşük bulunmuştur. Evlilerin alg1 genel puanları, bekarların alg1 genel puanlarından düşük bulunmuştur.

6. Yaş açısından katılanların yönetim puanları yaş değişkenine göre anlamlı farklılık göstermektedir. Farkın nedeni Yaş 18-30 olanların yönetim puanlarının yaş 31-45 olanların yönetim puanlarından yüksek olmasıdır. Yaş 18-30 olanların yönetim puanlarının yaş 46 ve üzeri olanların yönetim puanlarından 
yüksek olmasıdır. Katılanların algı genel puanları yaş değişkenine göre anlamlı farklılık göstermektedir. Farkın nedeni Yaş 18-30 olanların algı genel puanlarının yaş 31-45 olanların algı genel puanlarından yüksek olmasıdır. Yaş 18-30 olanların algı genel puanlarının yaş 46 ve üzeri olanların alg1 genel puanlarından yüksek olmasıdır. Katılanların hizmet puanları ise yaş değişkenine göre anlamlı bir farklılık göstermemektedir.

7. Eğitim durumu açısından ele alındığında katılanların hizmet, yönetim, algı genel puanları da eğitim durumu değişkenine göre anlamlı bir farklılık göstermemektedir.

8. Katılanların aylık gelirleri ile değerlendirildiğinde yönetim puanları aylık gelir değişkenine göre anlamlı farklılık göstermektedir. Farkın nedeni Aylık gelir 0-2500 tl olanların yönetim puanlarının aylık gelir 2501-5000tl olanların yönetim puanlarından yüksek olmasıdır. Aylık gelir 0-2500 tl olanların yönetim puanlarının aylık gelir 5001-7500tl olanların yönetim puanlarından yüksek olmasıdır. Aylık gelir 0-2500 tl olanların yönetim puanlarının aylık gelir 7500 tl üzeri olanların yönetim puanlarından yüksek olmasıdır. Katılanların algı genel puanları aylık gelir değişkenine göre anlamlı farklılık göstermektedir. Farkın nedeni Aylı gelir 0-2500 tl olanların alg1 genel puanlarının aylık gelir 2501-5000tl olanların alg1 genel puanlarından yüksek olmasıdır. Aylık gelir 0-2500 tl olanların alg1 genel puanlarının aylık gelir 7500 tl üzeri olanların alg1 genel puanlarından yüksek olmasıdır. Katılanların hizmet puanları aylık gelir değişkenine göre anlamlı farklılık göstermemektedir.

Bu sonuçlar 6360 Sayılı Yasa ile büyükşehir statüsüne geçen Hatay Büyükşehir Belediyesinin icra ettiği çalışmalara yönelik yerel halkın algisının ifadesidir. Sorulara alınan cevaplar ve yapılan analiz ile ortaya çıkan her sonuç değerli ve üzerinde çalışılması gereken önemli adımlardır. 
EXTENDED ABSTRACT

\title{
Public Perception about the Implementation of the Law No.6360: The Case of Hatay Metropolitan Municipality
}

\author{
Mehmet Tamer - Demet Dönmez \\ Hatay Mustafa Kemal University
}

In Turkey, as a result of the migration from rural to urban areas with the 1950s, the concentration of the population especially in big cities necessitated a change in the management of big cities. It found its constitutional basis for the first time with Article 127 of the 1982 Constitution, and then the process continued with some changes. Undoubtedly, every new regulation has been in the direction of eliminating existing deficiencies or meeting new needs. In this context, for the first time, the law numbered 3030 was enacted in 1984, and management styles specific to large settlements were introduced. The law stated that the purpose of the legal status of the metropolitan administration was to ensure that the services are carried out in a more planned, programmed and harmonious manner (art.1). Law No. 5216, which introduced new regulations regarding metropolitan administrations, was also adopted in 2004. It has been prepared in order to eliminate some of the problems encountered in the application of Law No. 3030 and to manage metropolitan cities more effectively. Many metropolitan municipalities have gained a special structure and their areas of responsibility have been expanded. In the ongoing process, Law No. 5747 adopted in 2008 also introduced new regulations regarding metropolitan administrations. However, the law was taken to the Constitutional Court for annulment by the main opposition party. Except for some issues, this request was rejected. The main change made with the Law No. 5747 was the scale reform. The last link of these regulations is the Law No. 6360, which was adopted in 2012 and entered into force with the 2014 local elections. The changes made can be listed as follows: - $\quad$ More than 14 provincial municipalities were made metropolitan municipalities, and the number of metropolitan cities increased to 30 . 
- In the existing metropolitan municipality model, which was established and operated as two-stage (metropolitan and district municipality) as of Law No. 5747, 1,076 town municipalities and 16,500 villages within the borders of the new metropolitan municipality due to this dual model have lost their legal personality, regardless of the population requirement of 2,000. turned into a neighborhood.

- In the provinces where metropolitan municipalities were established, sub-district and sub-district organizations were abolished. Subdivisions, which are the units belonging to the provincial organization of the central administration, are not foreseen in the provinces with metropolitan municipalities.

- Municipalities, which were transformed into villages by removing their legal personality, were allowed to join the neighboring provinces, districts and town municipalities with a population of more than 2000 as neighborhoods by the decision of the municipal council.

- The condition required for the establishment of a metropolitan municipality was changed to have the provincial population over 750,000 instead of the municipality population exceeding 750,000.

- In order to establish a new district municipality in metropolitan cities, the population criterion was reduced from 50,000 to 20,000 . This figure was set as 500 in order to establish a neighborhood.

- Special provincial administrations were abolished in 30 metropolitan municipalities. The number of special provincial administrations was reduced from 81 to 51. Investment Monitoring and Coordination Departments affiliated to governorships were established in these provinces to replace the abolished special provincial administrations.

The law, which brought radical changes, has been subject to some controversy since the day it was implemented. Especially in the provinces that have just gained metropolitan status with the said law, the restructuring process has brought problems in implementation. One of these provinces is Hatay. In Hatay, one of the oldest settlements in Anatolia, historical findings in terms of life date back to BC. It dates back to 100000 . 
There are fifteen districts in the province of Hatay, which is the metropolitan city of the Law No. 6360 enacted in 2012. Each district has a different history. It has an economy based on agriculture and industry. After the Syrian Crisis, it has been exposed to a large number of refugee migration. The population of the province is $1,659,320$ according to 2020 data.

Considering the area served and population density, ensuring efficiency in the provision of local services is undoubtedly of particular importance for the Hatay metropolitan administration. In order to detect the existing problems and to solve the problems, first of all, it is necessary to know how the current law is perceived by the citizens who receive service. The subject of this study is how the services made in the province of Hatay and the works done by the Hatay Metropolitan Municipality are evaluated by the people of the province. In this context, randomly selected citizens living in fifteen districts of Hatay province formed the sample of the study.

\section{Kaynakça / References}

Arıkboğa, E. (2013). Geçmişten geleceğe büyükşehir belediye modeli. Yerel Politikalar, 3, 48-96.

Bulut, Y. and Dönmez, D. (2019). 6360 sayılı düzenlemeyle oluşan büyükşehir modelinde büyükşehir belediyesi ile ilçe belediyeleri arasında yaşanan sorunlar ve çözüm önerileri: Hatay ili örneği. Uluslararası Yönetim Akademisi Dergisi, 2(1), 29-40. DOI:10.33712/mana.551905.

Çalcalı, Ö. (2014). 6360 Sayılı Kanun'un Türkiye'de yerel yönetimler sistemine getireceği değişiklikler. Çă̆daş Yerel Yönetimler Dergisi, 23(4), 49-68.

Çelikyay, H. (2014). Değişen kent yönetimi ve 6360 Sayılı Büyükşehir Yasası. Seta Analiz, 101, 6-22.

Derdiman, R. C. (2012). Türkiye'de Büyükşehir Belediyelerinin ve bu belediyelerin yapılarındaki yeni değişikliklerin anayasaya uyumu sorunu. Süleyman Demirel Üniversitesi Hukuk Fakültesi Dergisi, 2(1), 51-87. 
Günal, A., Atvur, S. and Dernek, K. O. (2014). 6360 Sayılı Yasanın yerelleşme bağlamında değerlendirilmesi. Süleyman Demirel Üniversitesi İktisadi ve İdari Bilimler Fakültesi Dergisi, 19(3), 55-70.

Günday, M. (2011). İdare hukuku (10. Baskı). Ankara: İmaj Yayınevi.

Kaymal, C. (2017). Yerel özerklik ve yerel demokrasi açısından büyükşehir belediyesi reformu. Ulakbilge Sosyal Bilimler Dergisi, 5(13), 1137-1159.

Kızılboğa, R. ve Alıcı, O. V. (2013). Türkiye'de kırsal alan belediyeciliği ve büyükşehir belediyelerinde il mülki sınırı uygulaması. Türk İdare Dergisi, 476, 353-381.

Oktay, T. (1998). Türkiye'de Büyükşehir Belediye Yönetiminin Tarihsel Gelişimi ve Mevcut Sistemin Değerlendirilmesi. Öneri Dergisi, 2(10), 63-70.

Oktay, T. (2016). 6360 Sayılı Kanun'a dayalı Büyükşehir Belediye reformunu anlama ve anlamlandırma. Siyasal Bilgiler Fakültesi Dergisi (ISMUS), I/1 (2016), 71-131.

Özçelik, Y. (2014). Büyükşehir belediyesi ile ilçe belediyeleri arasındaki ilişkiler. Türkiye Adalet Akademisi Dergisi (TAAD), 19, 1117-1142.

Özdemir, S. and Meşhur, M. Ç. (2011). 5216 Sayılı Büyükşehir Belediyesi Yasası'nın belde belediyelerinin planlama süreçleri üzerinde yarattığ1 etkiler. Megaron, 6(3),171-184.

Özgür, H. ve Yavuzçehre, P. S. (2016). Türkiye'nin büyükşehir belediyesi sistemi: 1982-2015. Çankırı Karatekin Üniversitesi Sosyal Bilimler Enstitüsü Dergisi, 7(1), 903-926.

Tekin, Ö. F. (2018). Türkiye'de büyükşehir yönetimi ve 6360 sayılı yasanın getirdiği değişim: Konya örneği.Dumlupınar Üniversitesi Sosyal Bilimler Dergisi, 55, 84-105.

Tortop, N., Aykaç, B., Yayman, H. ve Özer, M. A. (2006). Mahallî İdareler. Ankara: Nobel Yayınları.

Yılmaz, V. ve Kaypak, Ş. (2017). 6360 Sayılı Yasa ile getirilen yeniliklerin yerel halk üzerindeki etkililiğinin ölçülmesi: Malatya Büyükşehir Belediyesi örneği. International Journal of Academic Value Studies, 3(15), 405-418.

Yılmaz, V. ve Kaypak, Ş. (2019). 6360 Sayılı Yasa sonrası yeni büyükşehir belediyelerindeki çevre sorunlarının irdelenmesi: Malatya Büyükşehir Belediyesi örneği. Kent Akademisi, 12(1), 1-28.

Zengin, O. (2014). Büyükşehir belediyesi sisteminin dönüşümü: Son on yllın değerlendirmesi. Ankara Barosu Dergisi, 2, 91-116. 
5216 Sayılı Büyükşehir Belediye Kanunu

6360 Sayılı On Üç İlde Büyükşehir Belediyesi ve Yirmi Altı İlçe Kurulması ile Bazı Kanun ve Kanun Hükmünde Kararnamelerde Değişiklik Yapılmasına Dair Kanun

http://hatay.gov.tr/tarihsel-surec-icinde-hatayda-kultur-ve-uygarlik (Erişim: 12.02.2021).

\section{Kaynakça Bilgisi / Citation Information}

Tamer, M. ve Dönmez, D. (2021). 6360 Sayılı Yasanın uygulanmasına yönelik halkın algısı: Hatay Büyükşehir Belediyesi örneği. OPUS-Uluslararası Toplum Araştırmaları Dergisi, 18(Yönetim ve Organizasyon Özel Says1), 1758-1784. DOI: 10.26466/opus.891398. 